\title{
KREASI SENI SEBAGAI DAYA TARIK WISATA BUDAYA DI PADEPOKAN BAGONG KUSSUDIARDJA YOGYAKARTA
}

\author{
Oleh \\ Yulianto \\ Dosen Akademi Pariwisata Bina Sarana Informatika Yogyakarta \\ email: yulianto.ylt@bsi.ac.id
}

\begin{abstract}
Yogyakarta is a city of education and cultural city as well as tourist areas are still waking life order of the society and various art and cultural activities are still maintained its authenticity. Art creations that there dipadepokan is one of the cultural heritage, both in the form of classical dance, dance creations, Ballet, theatre, senirupa and others which are the legacy of the Bagong Kussudiardja. The research method used is descriptive qualitative research with data collection techniques derived from primary data is information obtained from primary sources and secondary data is data capture techniques through observation, interview, documentation and literature.

Some of the art creations in Bagong Kussudiardja is one of the artists to create and store a variety of works that made some of the Bagong Kussudiardja one of Cultural Attractions in Yogyakarta. Art creations are dipadepokan : jagongan wagen, estuary, angjasana, edukreasi, fine art, among the classical dance, sedulur Ballet, dance, dances and other activities is a form of art and cultural works with the aim that the some of the Bagong Kussudiadrja is one of the cultural heritage in Yogyakarta and Indonesia
\end{abstract}

Keywords: creative arts, arts education, cultural tourism

\section{PENDAHULUAN}

Yogyakarta sebagai kota perjuangan, pusat kebudayaan dan pusat pendidikan juga dikenal dengan kekayaan potensi pesona alam dan budayanya sampai sekarang dan masih tetap merupakan daerah tujuan wisata yang terkenal di Indonesia dan Mancanegara. Yogyakarta masih terjaga tatanan kehidupan masyarakat jawa khususnya dalam kehidupan sehari-hari yang tercermin pada kegiatan adat istiadat, sosial kemasyarakatan, kesenian dan sebagainya. Seni Budaya yang masih terjaga keaslian dan keindahan terdapat di Istana Raja dan daerah sekitarnya yang merupakan peninggalan kerajaan besar maka Yogyakarta memiliki kebudayaan yang tinggi dan bahkan pusat sumber kebudayaan Jawa. (Dinas Pariwsata, 2011).

Daerah Yogyakarta yang relatif aman dan nyaman dengan keramahtamahan masyarakatnya, menjadikan Yogyakarta banyak diminati orang atau wisatawan untuk berkunjung ke daerah Yogyakarta. Tidak mengherankan setiap tahun jumlah kunjungan wisatawan baik 
wisatawan mancanegara (wisman) maupun wisatawan nusantara (wisnus) yang datang ke Yogyakarta terus meningkat. Hal ini menunjukan semakin meningkatnya kepercayaan wisatawan dari luar Yogyakarta terhadap situasi dan kondisi Yogyakarta. Maka masyarakat Yogyakarta semakin dituntut untuk sadar wisata dan menerapkan Sapta Pesona, menjaga dan meningkatkan kepedulian kelestarian lingkungan. Dengan demikian diharapkan Yogyakarta semakin dikenal menuju tahun 2025 Yogyakarta sebagai daerah Tujuan Wisata Terkemuka di Indonesia maupun di Asia Tenggara.(Dinas pariwsata, 2013)

Jumlah Obyek wisata di Daerah Istimewa Yogyakarta tahun 2012 yang meliputi obyek wisata alam, obyek wisata budaya, obyek wisata buatan dan desa/ kampung adalah sebanyak 265 Obyek Wisata. Keseluruhan kunjungan Wisatawan Mancanegara ke obyek-obyek wisata tersebut sebanyak 499.515 orang, sedangkan wisatawan Nusantara mencapai 10.880.125 orang jadi totalnya mencapai 11.379 .640 orang.

Yayasan Bagong Kussudiardja yang merupakan lembaga nirlaba yang mengelola aset padepokan seni sebagai rumah budaya terbuka bertujuan untuk merekatkan dan membangun kebersamaan seni dengan masyarakat. Orientasi sebagai organisasi yang memberikan pelayanan (service organization), melalui pengelolaan dan mengembangkan praktek-praktek di dalam aktivitas seni pertunjukan sebagai media pembelajaran yang edukatif dan aplikatif kepada komunitas seni masyarakat. Tujuan didirikan Padepokan Bagong Kussudiardja untuk menjadi rumah budaya terdepan dalam memberikan kontribusi yang memperkaya dunia seni di Indonesia, sebagai jembatan yang merekatkan seni dengan masyarakat. Padepokan Bagong Kussudiardja memiliki ikthiar untuk merangsang kegairahan perkembangan kebudayaan dan pengembangan kreativitas masyarakat Indonesia.

Rumah budaya Padepokan Bagong Kussudiardja yang mewujudkan seni pertunjukan sebagai media dialog dan pembelajaran untuk merangsang kegairahan kreativitas komunitas seni dan masyarakat. Yayasan Bagong Kussudiardja mengolah proses-proses pembelajaran tentang seni dan menggunakan seni sebagai media, melalui presentasi karya seni pertunjukan, fasilitas pengembangan daya kerja kreatif seniman ( artistik dan non artistik), serta merencanakan dan membangun program yang meningkatkan penyertaan aktif masyarakat bersama dengan masyarakat.

Kreasi seni yang ada di Padepokon Bagong Kussudiardja bervariatif hal ini dan merupakan aset budaya dan merupakan aset pariwisata di Yogyakarta yang cukup edukatif dan aplikatif yang ditunjukan dengan seni pertunjukan yang membantu kunjungan pariwisata baik domestik maupun internasioanal. Strategi promosi yang lebih efektif dan mampu mengikuti persaingan yang cukup tinggi di dunia promosi. Kemampuan Sumber Daya Manusia sebagai sumber utama dalam pengembangan promosi di Padepokan Seni Bagong Kussudiardja agar dapat exist dan mampu menghadapi perkembangan budaya yang perubahannya cukup cepat. Kreasi seni tentunya jangan sampai terkikis dan hilang adanya era globalisasi dan informasi yang cepat tentunya membawa perubahan berbagai aspek kebudayaan. Informasi sangat penting untuk melihat kebudayaan baik nasional maupun internasional sebagai tolak ukur agar ragam kegiatan seniman mampu menghasilkan karya-karya baru tanpa meninggalkan ciri khusus seni yang ada di Padepokan Bagong Kussudiardja yang ada di Kembaran Tamantirto Kasihan Bantul.

Berdasarkan uraian diatas maka dapat di rumuskan sebagai berikut : 
1. Ragam kreasi seni apa saja yang ada di Padepokan Bagong Kussudiardja sebagai daya tarik wista budaya.

2. Strategi apa untuk menarik pengunjung agar dapat datang ke Padepakan Bagong Kussudiardja

\section{LANDASAM TEORI}

\section{Pengertian Kebudayaan}

Pengembangan Pariwisata Indonesia yang menggunakan konsepsi pariwisata budaya dirumuskan dalam Undang-undang Pariwisata Nomor 09 Tahun 1994, bahwa pariwisata budaya merupakan salah satu jenis kepariwisataan yang dikembangkan bertumpu pada kebudayaan Indonesia yang berdasarkan Pancasila. Setiap langkah dan gerak dalam kerangka pengembangan pariwisata secara normatif diharapkan tetap bertumpu pada kebudayaan bangsa, dengan demikian segala aspek yang terkait dengan pariwisata seperti promosi, atraksi, arsitektur, etika, organisasi, pola manajemen, makanan, souvenir diharapkan sedapat mungkin menggunakan potensi kebudayaan, kedudukan seni dan kebudayaan dalam pengembangan pariwisata Indonesia, tidak saja sebagai media pendukung, tetapi juga sebagai pemberi "identitas" kepada masyarakat itu sendiri.

Kebudayaan menurut oka A.Yoeti (2006), suatu entitas yang otonom dalam kehidupan manusia, dapat dipengaruhi oleh faktor-faktor tertentu dalam konstelasi sosial maupun lingkungan alamiah. Komponen pokok kebudayaan pertama, pandangan menyatakan bahwa kebudayaan par excellanece adalah nilai-nilai budaya beserta segala hasil pemikiran manusia dalam masyarakat, sedangkan tingkah laku dan benda-benda adalah akibat ikutan belaka dan kedua, kebudayaan adalah keseluruhan hasil pemikiran, pola tingkah laku, maupun benda-benda karya manusia. Kebudayaan bagaikan sebuah rumah, dimana seorang merasa aman di dalamnya. Rasa aman dapat menjadi pandu dalam setiap perjalanan mencari makna hidup, sebaliknya ketiadaan orientasi nilai dapat membuat orang resah atau tidak peduli.

Budaya sangat penting perannya dalam pariwisata, salah satu yang menyebabkan orang ingin melakukan perjalanan wisata adalah adanya keinginan untuk melihat cara hidup dan budaya orang lain dibelahan dunia lain serta keinginan untuk mempelajari budaya orang lain tersebut. Industri pariwisata mengakui peran budaya sebagai faktor penarik dengan mempromosikan karakteristik budaya dari destinasi. Sumber daya budaya dimungkinan untuk menjadi faktor utama yang menarik wisatawan untuk melakukan perjalanan wisata.

Sumber daya budaya yang bisa dikembangkan menjadi daya tarik wisata diantaranya : a). Bangunan sejarah, situs, monumen, galeri seni, situs budaya kuno dan sebagainya, b). Eni dan patung kontemporer, arsitektur, tekstik, pusat kerajinan tangan dan seni, pusat desain, studio artis, industri film dan sebagainya, c).Seni pertunjukan, drama, sendratari, lagu daerah, teater jalanan, eksibisi foto, festifal dan even khusus lainnya, d). Peninggalan keagamaan seperti pura, candi, masjid, situs dan sejenisnya, e). Kegiatan dan cara hidup masyarakat lokal, sistem pendidikan, sanggar, teknologi tradisional, cara kerja dan sistem kehidupan setempat, f). Perjalanan (trekking) ke tempat sejarah menggunakan alat transportasi unik. (I Gede Pitana, 2009)

Seni Budaya menurut Oka A.Yoeti (2006) adalah ekspresi dari jiwa seseorang yang terjadi oleh proses karya dan karsa. Penampilan yang ekpresif dari penciptaannya, kesenian mempunyai kaitan erat dengan unsur-unsur kebudayaan. Seni budaya (kesenian) dapat digolongkan menjadi seni pertunjukan (seni tari, seni teater, seni musik, seni pencak silat); Seni Rupa (seni murni, seni lukis, seni patung, 
seni kriya, dan seni desain). Seni Sastra (prosa atau puisi).

Hakekat kebudayaanlah yang menyebabkan manusia menjadi manusiawi, sebagai makhluk rasional, mampu menilai hal-hal yang kritis dan mempunyai rasa kewajiban moral. Manusia bisa melakukan penilaian dan membuat pilihan-pilihan sesuai dengan kehendaknya. Kebudayaan pula yang memberikan manusia suatu kemampuan untuk mengerti dirinya, menyadari kekurangan dan menunjukan keberhasilannya sendiri, tak pernah berhenti untuk mencari dan menciptakan karya budaya.

Ditinjau dari wujud kebudayaan memiliki 3 aspek utama, yaitu Ide (gagasan), wujud (bentuk) dan perilaku dan ditinjau dari segi isi, kebudayaan memiliki 7 unsur pokok, unsur bahasa, organisasi sosial, sistem perekonomian, sistem teknologi, sistem kepercayaan, sistem pengetahuan dan sistem kesenian, masing-masing sistem ini apabila dikaitkan dengan karya seni cipta budaya selalu bersinggungan akrab, karena selalu berkaitan.

\section{Pengertian pariwisata}

Menurut Undang-undang RI No. 10 tahun 2009, pariwisata adalah berbagai macam kegiatan wisata dan didukung berbagai fasilitas serta layanan yang disediakan oleh masyarakat, pengusaha dan pemerintah.

Pariwisata menurut Nyamon S. Pendit (2006), adalah salah satu jenis industri baru yang mampu mempercepat pertumbuhan ekonomi dan penyediaan lapangan kerja, peningkatan penghasilan, standar hidup serta menstimulasi sektor-sektor produktif lainnya.

Menurut World Trade Organization (WTO) dalam buku Ismayanti (2010) mengungkapakan pariwisata diartikan sebagai kegiatan manusia yang dilakukan perjalanan ked an tinggal di daerah tujuan di luar lingkungan kesehariannya.

\section{Pengertian kesenian}

Kesenian adalah perwujudan dari bentuk-bentuk yang ekspresif atau bentukbentuk ekspresi dari seseorang. Sebagai bagian kebudayaan kesenian dapat digolongkan menjadi tiga golongan yaitu seni rupa, misalnya seni patung, kria, seni grafik, seni reklame, seni arsitektur dan seni dekorasi. Seni pertunjukan misalnya seni tari, karawitan, seni musik deklamasi dan seni drama. Seni audio visual misalnya seni video, seni film (Kusmayati, 2000).

Kesenian menurut Bagong Kussudiardja (2000) adalah bagian kebudayaan. Seni Tari adalah keindahan bentuk anggota badan manusia yang bergerak, berirama dan berjiwa yang harmonis. Keindahan bentuk meliputi jari-jari tangan, pergelangan tangan, badan, leher bahu, pinggul, kaki, lutut dan pergelangan kaki, bentuk ini dapat berdiri sendiri atau dipadukan, sehingga merupakan kesatuan, keindahan gerak meliputi anggota badan manusia yang telah berbentuk kemudian digerakan baik sendiri-sendiri atau bersambungan dan bersama, Keindahan irama setelah anggota badan terbentuk dan digerakan maka harus berirama cepat maupun lambat, keindahan jiwa setelah bentuk, gerak dan irama dilahirkan oleh jiwa manusia, maka untuk melaksanakan apa yang dikehendaki manusia, maka untuk melaksankan harus dengan kemampuan menjiwai. Keindahan harmoni setelah bentuk gerak, irama dan jiwa yang dilahirkan oleh kekuatan jiwa manusia harus ada harmoni, harmonis inilah yang melahirkan keindahan.

Menurut Havland, 1975 dalam bukunya Kusmayati (2000). Seni pertunjukan dapat dipilah menjadi kesenian tradisi, kesenian modern dan kesenian massa, kesenian tradisi merupakan kesenian yang berasal dari tradisi masyarakat lokal yang berkembang secara turun temurun minimal dua generasi. 
Kesenian modern adalah kesenian yang dikembangkan dari tradisi yang disesuaikan dengan kebutuhan modern. Kesenian masa yang diubah perannya sebagai tontonan yang dapat menarik massa sebanyak-banyaknya.

Menurut Zeppel dan Hall (1992) dalam bukunya Oka A. Yoeti (2006) seni pertunjukan sebagai heritage tourism yaitu bagian dari pariwisata budaya yang menceritakan secara ringkas kepada pengunjung tentang pentingnya motivasi budaya. Seni pertunjukan baik tradisional, kontemporer maupun modern merupakan salah satu bentuk dari atraksi wisata, dan dapat berupa special event yang menjadi andalan atau daya tarik wisata. Berpijak pada prinsip-prinsip pengembangan pariwsata berkelanjutan, maka seni pertunjukan dalam konteks pariwisata idealnya didasarkan pada penggalian warisan budaya masyarakat setempat agar dapat menggambarkan karakteristik daerah bersangkutan.

\section{Daya tarik wisata Budaya}

Menurut Undang-undang Republik Indonesia Nomor 10 Tahun 2009 tentang kepariwisataan, daya tarik wisata adalah segala sesuatu yang memiliki keunikan, keindahan dan nilai yang berupa keanekaragaman kekayaan alam, budaya dan hasil buatan manusia yang menjadi sasaran atau tujuan kunjungan wisatawan. Keadaan alam, flora dan fauna, sebagai karunia Tuhan Yang Maha Esa, serta peninggalan purbakala, peninggalan sejarah, seni dan budaya yang dimiliki bangsa Indonesia merupakan sumber daya dan modal pembangunan kepariwisataan untuk peningkatan kemakmuran dan kesejahteraan rakyat sebagaimana terkandung dalam pancasila dan pembukaan Undang-undang Dasar Republik Indonesia Tahun 1945.

Menurut Yoeti (2006) Daya tarik wisata dibagi menjadi empat bagian yaitu;

1. Daya tarik wisata alam, yang meliputi pemandangan alam, laut, pantai dan pemandangan alam lainnya.

2. Daya tarik wisata dalam bentuk bangunan, yang meliputi bersejarah dan modern, monumen, peninggalan arkeologi, lapangan golf, toko dan tempat perbelanjaan lainnya.

3. Daya tarik wisata budaya yang meliputi sejarah, faktor, agama, seni, teater, hiburan dan museum.

4. Daya tarik wisata sosial, yang meliputi cara hidup masyarakat setempat, bahasa, kegiatan sosial masyarakat, fasilitas dan pelayanan masyarakat.

Selain empat komponen tersebut, daya tarik wisata juga harus memiliki komponen aksesibilitas dan amenitas (Damanik dan weber, 2006). Aksesibilitas mencakup sarana dan prasarana transportasi yang menghubungkan daya tarik wisata yang satu dengan daya tarik wisata yang lain di daerah tujuan wisata mulai dari transportasi darat, laut dan udara. Aksesibilitas juga mencakup peraturan atau regulasi pemerintah mengatur tentang rute dan tarif angkutan. Amenitas adalah insfrastruktur yang menjadi bagian dari kebutuhan wisatawan seperti fasilitas akomoadsi, restoran, bank, penukaran uang, telekomunikasi, usaha penyewaan (rental), olahraga, informasi dan lain sebagainya.

Menurut Damanik dan Weber (2006) daya tarik wisata yang baik sangat terkait dengan empat hal, yakni memiliki keunikan, orijinalitas, otentisitas dan keragaman. Keunikan diartikan sebagai kombinasi kelangkaan dan ke khasan yang melekat pada suatu daya tarik wisata. Orijinalitas mencerminkankeaslian ataukemurnian yakni seberapa jauh produk tidak terkontaminasi atau tidak mengadopsi nilai yang berbeda dengan nilai aslinya. Otentisitas lebih sering dikaitkan dengan tingkat keantikan atau eksotisme budaya sebagai daya tarik wisata. Otentisitas merupakan katagori nilai yang memadukan sifat alamaih, eksotis dan bersahaja. 
Konsep yang perlu diperhatikan dalam perencanaan daya tari wisata, diantaranya meliputi :

5. Penciptaan dan pengelolaan daya tarik wisata

Suatu kesalahan yang sering terjadi dalam pengelolaan daya tarik wisata adalah pemetaan daya tarik wisata yang terlalu prematur. Sebelum ada pengelolaan yang baik daya tarik wisata belum dapat difungsikan dan dipromosikan karena dengan kunjuungan wisatawan yang membludak akan dapat merusak sumbersumber daya yang ada, selain daya tarik wisata perlu juga diperhitungkan pengelolaan terhadap sarana pariwisata yang lain seperti tempat parkir, tour dan interpretasi.

6. Pengelompokan data tarik wisata

Sebuah daya tarik wisata yang lokasinya jauh memerlukan banyak waktu dan biaya untuk mencapainya sehingga menjadi kurang diminati wisatawan. Sistem pariwisata masal seperti kereta api cepat dan transportasi udara mengharuskan wisatawan berhenti dan melanjutkan perjalanan sebelum puas menikmati data tarik wisata yang sedang dikunjungi dengan baik. Alatalat transportasi ini juga mendorong perencanaan beberapa data tarik wisata harus berdekatan, karena itu kunjungan ke daya tarik wisata utama sebaiknya dikelompokan atau digabung dengan daya tarik wisata pelengkap yang lain. Contoh : Kunjungan ke taman nasional sebagai atraksi utama, menawarkan banyak atraksi wisata alam pelengkap seperti pemandangan, hiking, konservasi kehidupan liar, topografi yang menantang dan tempat rekreasi di luar ruangan.

7. Gabungan atraksi dan pelayanan

Meskipun daya tarik wisata merupakan porsi utama dalam sebuah pengalaman perjalanan, tetapi daya tarik wisata tetap memerlukan dukungan pelayanan. Misalnya, dalam perencanaan sebuah taman budya yang serasa kurang lengkap apabila tidak memperhitungkan pelayanan pendukung seperti akomodasi dan restoran, tempat hiburan dan sebagainya. Karena itu daya tarik wisata yang agak jauh atau terpencil minimal menyediakan pelayanan makanan, toilet dan pusat-pusat pengunjung.

8. Lokasi daya tarik wisata

Lokasi yang ada di pedesaan dan kota-kota kecil memiliki aset yang dapat mendukung pengembangan daya tarik wisata karena beberapa segmen pasar ada yang lebih menyukai suasana kedamaian dan ketenangan didaerah pedesaan, karena itu kedepan perlu dilakukan perencanaan dan kontrol terhadap daya tarik wisata yang masih alami seperti perkebunan dan jalan-jalan pelosok pedesaan yang masih alami yang di dalamnya juga terdapat wisata seni budaya yang menunjukan identitas daerah pedesaan tersebut sehingga dapat dibentuk daerah-daerah atau desa-desa wisata yang sedang dikembangkan oleh pemerintah dengan tujuan untuk peningkatan kesejahteraan dan dapat membuka peluang usaha bagi generasi muda.

\section{METODE PENELITIAN}

Metode Penelitian tentang Kreasi Seni Pertunjukan pada jenis penelitian ini menggunakan penelitian deskriptif kualitatif. Menurut Bog dan Tailor seperti yang dikutip oleh Moeleong mendifinisikan metodelogi kualitatif sebagai prosedur penelitian yang menghasilkan data deskriptif berupa katakata tertulis atau lisan atau dari bentuk tindakan kebijakan (Moeleong,, 2006)

Teknik pengumpulan data bersumber dari data primer yang merupakan informasi yang diperoleh dari sumber-sumber primer yaitu yang asli, informasi dari tangan pertama atau responden dan data sekunder 
merupakan informasi yang diperoleh tidak secara langsung dari responden, tetapi dari pihak ketiga (Wardiyanta, 2006).

\section{a. Pengamatan langsung (direct obsevation)}

Metode Observasi yaitu cara memperoleh data yang dilakukan dengan cara mengamati dan mencatat secara sistematisk gejala- gejala yang diselidiki. Dengan meninjau kegiatan-kegiatan dan kondisi yang ada di Padepokan Bagong Kussudiardja tersebut. Penulis mendatangi langsung Padepokan Bagong Kussudiardja tersebut supaya penulis dapat melihat dengan jelas bagaimana keadaan yang ada di Padepokan Seni Bagong Kussudiardja

\section{b. Wawancara langsung (direct interview)}

Metode wawancara adalah proses tanya jawab dalam penelitian yang berlangsung secara lisan. Penulis melakukan wawancara terhadap pihak yang terkait yaitu pihak pengelola Padepokan Seni Bagong Kussudiardja dan bagi wisatawan yang berkunjung di Padepokan Bagong Kussudiardja tersebut

\section{c. Dokumentasi (Documentation)}

Dokumentasi ini dilakukan guna mendapatkan foto atau gambar ragam kegiatan seni pertunjukan yang diadakan di Padepokan Bagong Kussudiardja Desa Kembaran Tamantirto, Kasihan Bantul.

\section{d. Studi Pustaka (Literature)}

Studi Pustaka dilakukan untuk mencari dan mendapatkan data-data yang bersifat teoritis dan berhubungan dengan penelitian yang sedang dilakukan. Dengan mempelajari literatur-literatur, dan sumber-sumber lainnya dari internet yang berhubungan dengan penelitian. Pengumpulan data kepustakaan dilakukan terhadap data dan informasi dalam bentuk buku, laporan hasil penelitian yang telah dilakukan oleh berbagai pihak yang terkait dengan kreasi seni Padepokan Bagong Kussudiardja untuk membangun citra pariwisata yogyakarta.

\section{HASIL DAN PEMBAHASAN}

\section{Sejarah berdirinya Yayasan Padepokan Bagong Kussudiardja}

Bagong Kussudiardja adalah salah satu seniman dan budayawan besar yang pernah di miliki Bangsa Indonesia yang telah berhasil mengembangkan visi kebudayaan yang bertujuan membangun manusia Indonesia melalui seni. Aktivitas seni dan budaya yang secara konsisten diwujudkan sejak tahun 1950-an, hingga kemudian bermuara dengan didirikannya sebuah lembaga pendidikan seni non formal yang didirikannya pada tahun 1978. Pada tahun 2004, Bagong Kussudiardja wafat dengan mewariskan semangat kreativitas yang tinggi dan sebauah "Padepokan Seni" yang memerlukan keberlanjutan dalam pengelolaannya. Pemikiran bagi pengelolaan padepokan seni inilah, kemudian melahirkan Yayasan Bagong Kussudiardja.

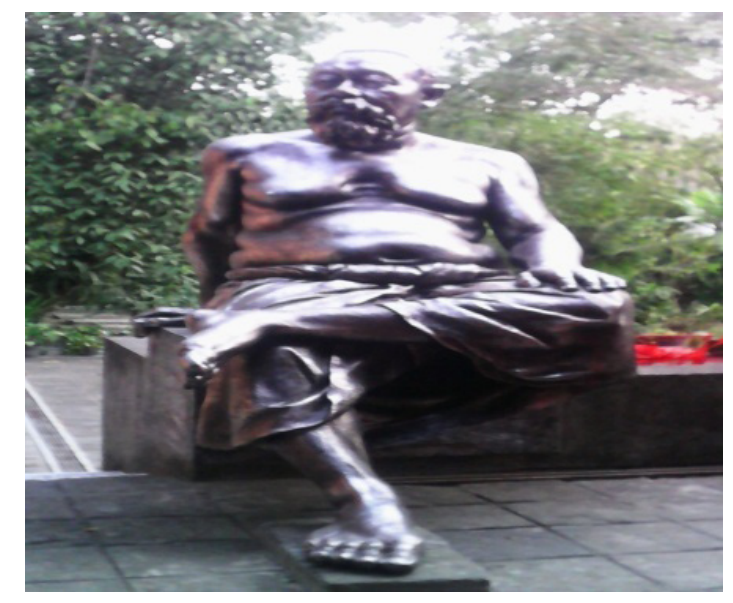

\section{Gambar : 1. Patung Bagong Kussudiardja}

\section{Visi}

Menjadi rumah budaya terdepan dalam 
memberikan konstribusi yang memperkaya dunia seni di Indonesia, sebagai jembatan yang merekatkan seni dengan masyarakat. Yayasan Bagong Kussudiardja (YBK) memiliki ikhtiar untuk merangsang kegairahan perkembangan kebudayaan dan pengembangan kreativitas masyarakat Indoensia, melalui peran aktif terhadap seni, komunitas seni, dan kebersamaan masyarakat dengan seni.

\section{Misi}

Yayasan Bagong Kussudiardja (YBK) adalah rumah budaya nirlaba di Yogyakarta yang mewujudkan seni pertunjukan sebagai media dialog dan pembelajaran untuk merangsang kegairahan kreativitas komunitas seni dan masyarakat. Yayasan Bagong Kussudiardja (YBK) mengolah proses-proses pembelajaran tentang seni dan menggunakan seni sebagai media, melalui presentasi karya seni pertunjukan, fasilitas pengembangan daya kerja kreatif seniman (artisik dan non artistik), serta merencanakan dan membangun program yang meningkatkan penyertaan aktif masyarakat bersama.

Letak Padepokan Bagong Kussudiardja berada diwilayah Desa Kembaran RT 04 Tamantirto Kasihan Bantul Yogyakarta, Padepokan Bagong Kussudiardja pada bagian timur berbatasan dengan Desa Tirtonirmolo, sebelah selatan Desa Gunungsempu. Disebelah barat desa Kasihan serta sebelah utara desa Ngrame. Padepokan Bagong Kusudiharjo jarak dari ibukota Bantul cukup jauh yakni $10 \mathrm{~km}$ sedang jarak dari pusat Kota Yogyakarta atau dari titik Nol $7 \mathrm{~km}$ yang dapat ditempuh 20 menit sedangkan dari kasongan (Sentra industry keramik berjarak $2 \mathrm{~km}$ )

Akses untuk menuju Padepokan Bagong Kussudiardja cukup terpenuhi dari lokasinya yang tidak jauh dari jalan utama tapi jalan menuju lokasi sudah diaspal dan parkiran juga luas baik untuk kendaraan pribadi bahkan parker Bus yang besar cukup menampung semua bagi pengunjung. Saat masuk gang ada reklame penunjuk arah yang besar ke padepokan Bagong Kussudiardja juga di fasilitasi ada hotspot.

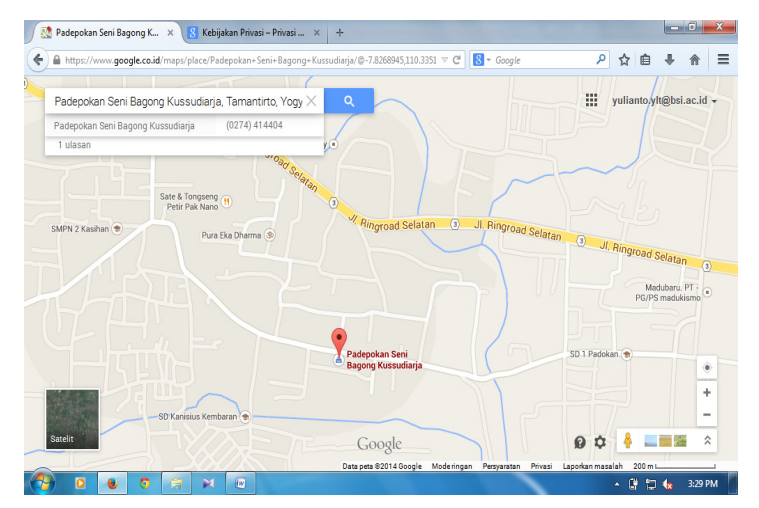

Gambar 2. Peta Padepokan Bagong Kussudiardja

\section{Fasilitas Padepokan Bagong Kussudiardja}

\section{Bangsal Diponogoro}

Bangsal Diponogoro sebagai tempat latihan tari dan kesenian lain yang terpadu dengan seni karawitan, sinden dan pedalangan serta sebagai ruang ujicoba pergelaran tari. Letak bangsal diponogoro di area depan Padepokan, diapit antara Wisma Damarwulan dan asrama siswa. Untuk penunjang ruangan yakni ruang karawitan (6x12m), berisi 1 set gamelan jawa, gudang peralatan dan tempat duduk penonton

\section{Saung Arjuna Wiwaha}

Saung Arjuna Wiwaha sebagai tempat latihan atau penguasaan gerak tari yang lebih bersifat rekreatif, karakteristik ruangan terbuka mirip dengan saung dab berukuran $5 \mathrm{~m} \times 5 \mathrm{~m}$

\section{Studio Tari Pribadi}

Studio ini tidak terpakai lagi semenjak Bagong Kussudiardja meninggal dunia, 
dahulu merupakan bagian dari rumah induk yang digunakan untuk berkontemplasi menciptakan karya-karya baru dan terletak antara Bangsal Layang-layang dan Asrama Siswa

\section{Pendopo penguasaan Gerak Tari}

Pendopa penguasaan gerak tari sebagai tempat latihan tari sering digunakan pula untuk latihan bersama tamu dari luar pedepokan, terletak di depan pintu masuk ke padepokan Bagong Kussudiardja yang besarnya ukuran ruang: $8 \mathrm{~m}$ x $10 \mathrm{~m}$.

\section{Ruang pagelaran}

Ruang pagelaran sebagai ruangan untuk berbagai pementasan baik tari, teather, music dan lain-lain yang disain sedemikian rupa baik untuk pemain maupun penonton bisa nyaman dalam melihat pertunjukan. Ruangan yang cukup luas dan juga tempat duduk dibuat berundak seperti amphiteather dan juga disediakan kursi.

\section{Kantor Pengurus Yayasan Bagong Kussudiardja}

Kantor Pengurus Yayasan Bagong Kussudiardja sebagai pusat administratif padepokan, tempat control pelaksanaan kegiatan di padepokan dan komunitas lain yang dibawah naugan Yayasan Bagong Kussudiardja. Bagian ruangan YBK terdiri tempat penerimaan tamu, Ruang Ketua dan Manajer Yayasan Bagong Kussudiardja, Ruang Karyawan dan ruang arsip.

\section{Studio karawitan dan rekaman}

Merupakan tempat latihan dan rekaman Orkes Sinten Remen dan Kuatnika serta tempat untuk penciptaan dan rekaman musik pengiring tari kreasi baru yang dilatihkan di padepokan Bagong Kussudiardja. Karakteristik bangunan : privat, membutuhkan ketenangan, akustik dan nyaman terdapat ruangan souvenir, ruang operator induk, ruang rekaman,
Kantor Kuaetnika dan Orkes Sinten Remen. Pada studio rekaman dan operator setiap bidang dinding dimiringkan sebesar $1^{0}$ terhadap lantai untuk mengatasi masalah gema sedangkan untuk ukuran ruangan $15 \mathrm{~m}$ x 9m (2 lantai)

\section{Galeri Lukisan}

Galeri lukisan merupakan tempat produk seni rupa bagi seniman dan merupakan ruang pameran karya seni rupa Bagong Kussudiardja sering diadakan pameran selama 1 bulan lebih dengan tujuan agar masyarakat lebih tau tentang dunia seni rupa tentunya hasil karya Bagong Kussudiardja.

\section{Ragam Kreasi Seni di Padepokan Bagong Kussudiardja}

\section{Anjangsana Edukreasi}

Kata padepokan yang tertulis pada Padepokan Seni Bagong Kussudiardja (PSBK), menunjukan tempat belajar atau tempat untuk belajar. Padepokan seni menunjukan bahwa tempat belajar tersebut adalah tempat belajar seni sedangkan, Bagong Kussudiardja yang tertera di depan kata seni adalah nama seorang tokoh seni dan seniman besar di kesenian yang mendirikan tempat belajar seni tersebut. Tempat belajar yang bernama padepokan, memiliki ciri yang lain dengan tempat belajar seni yang lain. Ciri belajar di tempat belajar yang bernama padepokan, bisa diketahui dan dikenali yang terlihat dan terdengar oleh manusia yang belajar dipadepokan Bagong Kussudiardja, pada apa yang terlihat dan yang terdengar pada aktivitas belajar dipadepokan dan berbagai kegiatan lainnya, sebab PSBK berciri (bertanda) dan bercirikan (berkekuatan) seni. Seni yang dipelajari di PSBK adalah seni yang berdasarkan dan berasal dari seni yang tumbuh dan berkembang kreasi seni baru di PSBK.

Pada tanggal 20 April 2011, PSBK 
melaksanakan program seni yang bernama ANJANGSANA, sebuah program penggiatan seni yang bersumber pada kebudayaan kebudayaan Nusantara. Yaitu kunjung-mengunjungitempathidup manusia. Beranjangsana merupakan salah satu cara pemuliaan hidup manusia (khususnya manusia Indonesia) yang sudah membudaya. Berkunjung untuk membangun persaudaraan dan saling memberikan persaudaraan dan saling memberikan dukungan pada tempat hidup manusia dan pada manusia yang menempatinya. Berkunjung untuk mengetahui dan mengenali keindahan hidup manusia yang menempatinya. Sehingga saling tahu dan saling kenal pada yang ada di dalamnya. Beranjangsana menjadi laku hidup/tindakan hidup yang dewasa dan mulia, serta mendewasakan dan memuliakan yang mengunjungi dan yang dikunjungi.

\section{Kegiatan Anjangsana}

\section{a. Berkunjung ke tempat belajar seni Teater Padepokan Seni Bagong Kussudiardja}

Ilmu seni yang ditumbuhkan dan dikembangkan di Padepokan Seni Bagong Kussudiardja (PSBK), satu diantaranya bersumber pada yang ada di seni teater. Dalam hal ini PSBK belajar dan berkarya di dalam dan melalui yang ada di seni teater. Caranya adalah memugari, membugari dan menyegari yang ada didalam dan melalui hidup manusia yang hendak, telah dan lanjut menumbuhkan dan mengembangkan :

1) Ilmu seni yang ada di dalam hidup manusia berteater

2) Ilmu seni yang ada aktivitas hidup manusia berteater

3) Ilmu seni yang ada di alat hidup manusia yang berteater

4) Ilmu seni yang ada di tempat hidup manusia yang berteater

\section{b. b. Tahu dan Pengetahuan}

Bila memperhatikan apa yang terlihat dan yang terdengar, akan mudah untuk mengetahui apa yang terlihat dan yang terdengar. Termasuk mengetahui seni dan pengetahuan tentang ilmu seni yang ada pada manusia yang berteater di Padepokan Seni Bagong Kusudiardja. Bila Tahu belajar dan belajar tahu pada yang diperlihatkan dan yang diperdengarkan manusia yang berseni teater, pasti dan niscaya tahu ajaran yang ada pada yang diperlihatkan dan yang didengarkan manusia yang bereni teater. Untuk tahu seni yang ada pada manusia yang berseni teater di Anjangsana bisa diketahui didalam dan melalui kesenangan, ketertarikan dan keterkejutan yang ada di manusia yang berseni teater.

\section{c. Kenal dan Pengenalan}

Setelah tahu dan mengetahui, dilanjutkan dengan belajar kenal dan kenal belajar, bahwa untuk belajar kenal dan kenal belajar ada yang disamakan dan ada yang dilainkan saat belajar. Adapun beberapa cara untuk mengenali dan mengenalkan yakni :

1) Mengenali dan mengenalkan pengetahuan seni yang ada pada teater.

2) Mengenali yang mengenalkan cara belajar seni-nya teater di Padepokan Seni Bagong Kussudiardja

3) Mengenali dan mengenalkan tubuh, suara dan kata yang berseni teater.

Padepokan Bagong Kussudiardja membuat cara yang tersendiri, untuk mengenali dan mengenalkan ilmu seni yang ada diteater. Cara yang dibuat PSBK, diawali dengan membuat kanal/ saluran pada diri manusia yang melihat dan mendengar (membuat diri), untuk menyalurkan apa yang pernah terlihat dan yang didengar.

\section{d. Jagongan Wagen}

Pargelaran dan apresiasi karya seni pertunjukan yang diselenggarakan secara terbuka dan rutin sekali pada 
tiap bulan di rumah budaya Yayasan Bagong Kussudiardja. Pergelaran seni pertunjukan adalah ruang sinergi yang mempertemukan semangat kebersamaan dan energi kreatif, mampu merangsang inspirasi dan imajinasi yang membangkitkan gairah hidup. Program ini meyakini dan memaknai kekuatan ruang pementasan seni pertunjukan sebagai media dan sarana untuk saling berbagi pengetahuan, energi kreatif dan kreatifitas yang senantiasa harus dijaga serta ditumbuhkan. Jagongan (bahasa jawa) adalah aktivitas kumpul bersama dan melakukan obrolan dalam suasana yang santai dan akrab. Wagen, selain kebetulan jatuh pada hitungan wage (nama dalam penanggalan jawa) pada saat pertama diselenggarakan, juga dimaknai sebagai putaran waktu atau berulang. Jadi Jagongan wagen sebagai ajang kumpul bulanan yang selalu ditunggu khalayak dalam sajian seni pertunjukan dan obrolan seputar seni dan karya itu sendiri.

\section{Muara}

Program ini merupakan fasilitasi ruang dan peluang yang mempertemukan seniman (komunitas seni) lintas disiplin bidang/media seni dan atau lintas budaya, untuk saling melakukan aktivitas (kreatif) pembelajaran bersama diantara mereka. Fasilitasi ruang pertemuan yang memberikan peluang dialog ini tidak semata bertujuan untuk mengembangkan suatu bentuk seni pertunjukan baru ataupun penciptaan karya yang dilakukan bersama-sama, tetapi lebih untuk meninggkatkan daya kritis dan perspektif dalam mempelajari dan memahami keberagaman dan perkembangan bentuk seni, ketrampilan (teknik) seni yang berbeda, metode proses kreatif penciptaan karya seni pertunjukan, serta kekuatan budaya yang menjadi latar belakang seniman.

\section{Among Sedulur}

Fasilitasi kegiatan kreatif dengan memanfaatkan seni pertunjukan sebagai sumber pembelajaran dan aktivitas saling berbagi yang mengangkat dan menyertakan masyarakat di dalam dan bersama dengan seni. Among sedulur terdiri 2 kegiatan utama yaitu : a) Anjangsana, apresiasi seni dalam bentuk pergelaran karya seni pertunjukan yang memiliki nilai edukasi kepada masyarakat, b) Among seni, aktivitas berbasis seni yang secara langsung dan aktif menyertakan masyarakat mengolah daya kreativitas dan proses penciptaan yang memiliki nilai kebersamaan

\section{Seni Rupa}

Padepoakan Seni Bagong Kussudiardja pada tahun 1978, keberadaan PSBK sejak berdirinya, telah menjadi pusat perhatian atas pertumbuhan dan perkembangan nilai seni yang ada dikesenian, baik yang diwujudkan dalam bentuk karya kesenian maupun yang diwujudkan untuk keindahan hidup manusia dan masyarakat.

Salah satu bentuk program presentasi di PSBK, ruang Seni Rupa (RSP) digulirkan untuk membawa masyarakat seni dan selain seni bersama berpartisipasi dalam mengembangkan imajinasi dan kapasitas belajar kreatif, di dalam dan melalui praktek Seni Rupa di PSBK, PSBK memfasilitasi proses bagi seniman-seniman yang belajar dan berkarya secara kolaboratif dalam menciptakan dan menyajikan kekuatankekuatan artistic berkesenian yang bersifat instalatif, performatif dan kolektif.

PSBK menghadirkan dan memberlangsungkan Program Presentasi sebagai wadah bagi seniman, sekaligus untuk memfasilitasi kekuatan proses penciptaan dan presentasi hasil belajar serta berkarya seni di PSBK.

Catatan dari ruang Seni Rupa AgustusSeptember 2014 merupakan sebuah anyaman kekuatan rupa yang dibangun dari seniman dengan berbagai lintas disiplin dalam 
membangun sebuah gagasan mengenai tekat yang kuat. Proses Suji hadir dalam ruang seni disusun oleh oleh seniman yang mencoba membongkarkembali atas pemaknaan "rupa" sebagai sebuah pertemuan gagasan dari berbagai disiplin ini melewati serangkaian proses yang berupa pertemuan kreatif yang memuarakan penemuan, eksplorasi dan perwujudan atas peristiwa yang terjadi di dalam diri maupun yang terjadi di dalam diri maupun yang terjadi di luar negeri.

Sebuah pergolakan kreatif yang disusun secara kolektif oleh seniman Ruang Seni Rupa Suji dimana bentuk yang bersifat performatif-instalatif dan interaktif mempertajam kedalaman diri dalam sebuah anyaman semangat karya dalam bentuk rupa, mengarisbawahi kekuatan diri dan kebulatan tekad yang menjadi kekuatan tajam setiap seniman yang berada diruang ini. Ruang Seni Rupa Suji menawarkan pemaknaan ulang atas keutuhan, dimana keperbedaan memberikan sebuah susunan yang indah atas arti utuh dan merdeka.

Bagong Kussudiardja pendidik tari yang punya keyakinan bahwa kreativitas dapat dilatihkan, kreatifitas dapat diasah, kreativitas dapat dipertajam, sensitivitas kreatif dapat dirangsang. Adapun tari yang ada di Padepokan Bagong Kussudiardja sebagai berikut :

\section{a. Tari Klasik}

\section{1). Tari Kuda-kuda}

Gagasan ini dari wayang yaitu adegan jaranan dan rampogan yang menggambarkan keberangkatan para prajurit ke medan perang. Tari kuda-kuda memang disiapkan dalam misi kebudayaan ke luar negeri dan diipentaskan diluar negeri tahun 1954. Tarian ini awalnya mendapat ejekan dari para pengamat seni tari waktu itu karena Bagong Kussudiardja merusak tarian dan membawa yang adiluhung kembali ke tarian primitif, soal durasi (running time)
6 menit (pendek), setelah pentas di luar negeri terdengar kabar tarian ini mendapat sambutan antusias penonton dimanca negara, baru respon publik lokal berubah. Sejak itu tumbuh keyakinan tari ternyata bisa diolah sekehendak hati sehingga terjadi kreativitas.

\section{2). Tari Layang-layang}

Tari layang-layang (1954) dibawakan pertama diluar dan ditarikan sendiri oleh Bagong Kussudiardja dengan iringan hanya satu gendang batangan dan satu gendang ben besar dimainkan oleh Basuki Kusworo.Kreativitas dipahami oleh Bagong Kussudiardja secara praktis dan sederhana, mengaku belum pernah belajar secara khusus teori kreativitas dari sudut pandang spikologi atau ilmu kepribadian, bahkan belajar estitikapun secara tidak langsung hanya dari pergaulan dengan guru-guru seninya di tari maupun seni rupa.

Kreativitas sebagai bentuk latihan mengasah rasa, mengolah pikiran dan memadukannya sehingga dapat menciptakan berbagai macam variasi gagasan dan perwujudan dalam karya, Penari tidak pasrah menerima keadaan, tinggal diam, dan tidak berbuat apa-apa ditengah macam keterbatasan, melatih kreativitas Bagong Kusdiahrjo cenderung memanfaatkan fasilitas yang ada. Kreativitas bukan sekedar yang aneh-aneh, kreativitas menuntut pertanggungjawaban, baik secara etika, estitika, persaan (subyektivitas emosi) maupun pikiran (subyektivitas nalar), serta norma-norma sosial lainnya. Kreativitas akan memberikan sumbangan begitu nyata bagi tingkat produktivitas menghasilkan karya, kreativitas juga berguna dalam mengatasi berbagai berbagai hambatan.

\section{b. Karya - Karya Sendratari Bagong Kussudiardja}

Arjuna Wiwaha, Lutung Kasarung, Joko Tarub, Roro Mendut, Halleluya, Kebangkitan dan Kelahiran Isa Almasih, 
Pesta desa, Pangeran Diponogoro, Gadjah Mada,Ratu Kidul I, Dosa Terampung, Barata Yuda, Kidung, Kembang Setaman, Kenangan Masa Lampau, Cupu Manik, Igeligelan, Murwakala, Pangeran Jayakarta, Panca Sakti, Prasapta Gita Nusantara, Damar Wulan, Ramayana, Ambiance, Minta Hujan, Mozaik Nusantara, Sekar Suko, Ronggeng, Sekar Kunang, Panca Sakti II, Radyan Asmara, Panji Semirang, Tirta Amarta, Jala Mukjizat, Manunggal, Uwel.

\section{c. Tari Kreasi di Pusat Latihan Tari Padepokan Bagong Kussudiardja}

\section{1). Tari itik}

Sebuah tarian yang menceritakan tentang sekumpulan itik yang sedang bermain bersama, lincah berlari kesanakemari dengan dikombinasi gerak tari dan berlenggok- lenggok ibarat itik yang berjalan lenggak lenggok dan melompat sangat lincah yang disertai keceriaan.

\section{2). Tari Kumbang}

Sebuah tarian yang menceritakan tentang sekumpulan kumbang yang sedang terbang dengan lincah bermain kesanakemari dengan ceriannya, kumbangkumbang tersebut sedang mencari bunga yang ingin dihinggapinya

\section{3). Tari Putri Jeruji}

Sebuah tarian yang menceritakan tentang seorang putri yang sangat pandai menari dengan mengkombinasikan gerak tarian jawa yaitu "ngeruji" dengan nuansa kostum penari dari kalimatan yang sangat indah dilihatnya dimana disetiap gerak tariannya hanya ada satu jenis gerakan yaitu ngeruji.

\section{4). Tari Cublak-cublak suweng}

Sebuah tarian yang menceritakan tentang salah satu permainan tradisional yang perlu dilestarikan yang dimainkan oleh lebih dari dua anak, dimana dalam tarian tersebut mengkombinasikan gerak tarian dengan permainan cublak-cublak suweng. Hal ini dalam permainan aka nada satu anak yang harus jaga yang bertugas mencari benda seperti batu atau kerikil yang disembunyikan oleh temannya.

\section{Strategi promosi untuk menarik kunjungan wisatawan.}

Dalam meningkatkan kunjungan wisatawan baik mancanegara maupun wisatawan domestik tentunya Pengelola Padepokan Bagong Kussudiardja selalu mengadakan promosi dengan mengadakan berbagai kegiatan pertunjukan seni yang ada di Padepokan Bagong Kussudiardja agar selalu eksis dalam bidang kesenian. Kegiatan untuk menarik wisatawan ke Padepokan Bagong Kussudiardja Bantul melalui :

\section{Promosi}

Kegiatan promosi merupakan suatu kegiatan yang intensif dalam relatif singkat. Dalam kegiatan yang diadakan selalu berusaha memperbesar daya tarik wisatawan. Untuk mengadakan promosi yang tepat harus disadari bahwa yang disampaikan masyarakat itu sering hanya komponenkomponen saja yang ada dilingkungan Padepokan Bagong Kussudiardja juga mempromosikan fasilitas apa saja yang menunjang pengunjung agar datang ke Padepokan Bagong Kussudiardja. Hal ini akan menjadi paket promosi baik internal maupun ekternal yang berhubungan.

Komponen-komponen itu yang masih harus disatukan sehingga menjadi suatu produk paket wisata yang lengkap, produk tersebut dapat disusun sendiri oleh wisatawan yang melakukan perjalanan. Sehingga promosi pun juga harus ditunjukan kepada mereka sedetail mungkin agar mereka cepat paham wisata tersebut.Hal ini disebut promosi langsung dilakukan oleh Padepokan Bagong Kussudiardja baik promosi satu 
paket wisata, melalui Facebook, WatshAAP, BBM, Twiiter,

\section{Public Relation}

Menjalin hubungan dengan masyarakat luas sangat berkaitan dengan promosi yang kita lakukan, hubungan dengan masyarakat tidak bertujuan untuk menjual suatu produk wisata Budaya saja namun berusaha untuk membuat pengelola wisata digemari oleh masyarakat pada umumnya tidak hanya kepada calon konsumen atau wisatawan. Kalau dapat kita gambarkan produsen atau pengelola adalah sebuah wajah maka peran hubungan masyarakat adalah membuat sebuah senyuman yang indah pada wajah tersebut.

Menciptakan hubungan dengan masyarakat tentunya akan menciptakan suasana yang akrab dan mampu membina dan menjalin hubungan antara Padepokan Bagong Kussudiardja dengan masyarakat sekitar maupun masyarakat pencinta seni denga tujuan utama adalah mendapat dukungan dari masyarakat sebanyak banyaknya dalam acara-acar yang digelar Padepokan Bagong Kussudiardja yang berupa seni pertunjukan.

Setiap elemen dalam bauran promosi dapat dilaksanakan oleh organisasi dalam mengkomunikasikan produk kreasi seni dan layanan yang baik kepada masyarakat. Penggunaan beberapa bauran promosi dapat lebih meningkatkan efektifitas komunikasi dalam memasarkan produk kreasi seni dan jasa kepada masyarakat.

Bauran pemasaran ini selalu dikaitkan dengan penyampaian sejumlah pesan dan penggunaan visual yang tepat sebagai syarat utama keberhasilan dari sebuah program promosi. Tahapan-tahapan komunikasi dan strategi pesan disusun berdasarkan pencapaian kesadaran atas keberadaan sebuah produk atau jasa (awareness), menumbuhkan sebuah keinginan untuk memiliki atau mendapatkan produk (interest), sampai dengan mempertahankan loyalitas pelanggan atau pencinta seni.

\section{KESIMPULAN}

Dalam pembahasan penelitian tentang Kreasi Seni di Padepokan Bagong Kussudiardja sebagai Daya Tari Wisata Budaya di Yogyakarta disimpulkan hasil penelitian ini adalah sebagai berikut:

1. Bahwa Padepokan Bagong Kussudiardja tempat kegiatan seni baik seni yang diciptakan Alm Bagong Kussudiardja yakni seni tari klasik, tari kreasi, sendratari maupun lukisan/seni rupa yang tentunya merupakan peninggalan karyakarya beliau yang menjadi peninggalan seni budaya. Kegiatan yang lain sebagai wadah atau tempat seperti jagongan wagen, muara, anjangsana edukreasi, among sedulur, Seni rupa dan ruang Pusat Latihan Tari (PLTI).

2. Setiap kegiatan atau event yang ada di Padepokan Seni Bagong Kussudiardja tentunya membutuhkan cara bagaimana mendatangkan pengunjung yakni melalui website, twitter, facebook, spanduk, baliho dan yang bersifat undangan ke berbagai instansi pemerintah dan swasta serta perguruan Tinggi terutama yang ada jurusan bidang seni.

3. Berbagai kreasi yang di ciptakan Alm Bagong Kussudiardja merupakan daya tarik wisata Budaya yang ada di Padepokan Bagong Kussudiardja Tamantirto Kasihan Bantul

4. Banyaknya kegiatan di Padepokan Bagong Kussudiardja berdampak pula terhadap warga sekitarnya dengan ditunjukan melalui penjualan dan parkir yang dikelola warga

\section{DAFTAR PUSTAKA}

Anonim, 2013, Yayasan Bagong 
Kussudiardja, from : www,ybk.or.id

Anomin, 2011, Statistik Kepariwistaan, Dinas Pariwisata Provinsi Daerah Istimewa Yogyakarta

Anonim, 2013. Statistik Kepariwisataan, Dinas Pariwisata Propinsi Daerah Istimewa Yogyakarta

Bagong Kussudiardja, 2000. Dari Klasik hingga Kontemporer, Yogyakarta, Padepokan Press.

Oka A Yoeti, 2006, Pariwisata Budaya,
Jakarta, PT.Pradnya Paramita.

Moeleong,Lexy, 2006. Metode penelitian kualitatif, Bandung .PT.Remaja Rosda Karya

Nyoman S. Pendit, 2006. Ilmu Pariwisata, PT.Pradnya Paramita, Jakarta

I Gede Pitana dan I ketut Surya Diarta, 2009. Pengantar Ilmu Pariwisata, Yogyakarta Penerbit Andi

Sutopo, HB, 2006. Metode Penelitian Kualitatif, Surakarta.UNS, Press 